\title{
Detoxification of Benzoic Acid in Workers Exposed to Toluene Using Food Rich in Glycine
}

\author{
Abdul Rohim Tualeka1, Michael Agung Irianto1 Adli Prasetyo1, \\ Ike Agustin Rachmawati, Erwin Dyah Nawawinetu2

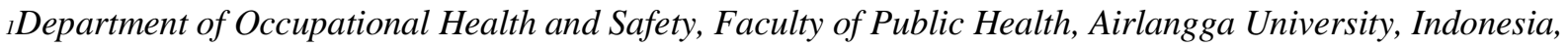 \\ ${ }_{2}$ Diploma Study Program of Industrial Hygiene and Occupational Health, Universitas Airlangga, Indonesia
}

\begin{abstract}
One of the toxins found in shoe industry affecting the health of the workers is toluene. Toluene contains safat, a high toxicity with liver and kidneys as the main targets. This research aims to determine the effects of consuming food rich in glycine on hippuric acid levels in the urine of shoe industry workers exposed to high levels of toluene. This research is an experimental study using certain treatments for the research subjects consisting of workers exposed to toluene at some shoe home-industries. Before working, the workers were examined for hippuric acid level in their urine. The workers were then given food rich in glycine to eat. After three days of consuming food containing glycine, the workers were examined again for hippuric acid level in their urine. The findings of the study showed that the level of toluene in the shoe home-industry A was 511.8 $\mathrm{mg} / \mathrm{m}_{3}$ which was three times greater than the standard reference of the normal toluene level recommended by Permenakertrans No.13 of $2011\left(168 \mathrm{mg} / \mathrm{m}_{3}\right)$. The results also showed that the mean concentration of hippuric acid in their urine before consuming food rich in glycine was $0.4855 \mathrm{~g} / \mathrm{L}$ while the mean concentration of hippuric acid in their urine after the intake of food containing glycine was $0.649 \mathrm{~g} / \mathrm{L}$. It means that there was an increase of 33.8\% in hippuric acid levels secreted in their urine. In conclusion, glycine is effective to detoxify benzoic acid from the body of workers exposed to toluene.
\end{abstract}

Keywords: toluene, workers, benzoic acid, glycine, hippuric acid

\section{INTRODUCTION}

Raw materials used in the production process of shoes, such as adhesives and paints, contain organic solevents. The solevents are mainly composed of benzene, xylene, ethyl benzene, toluene, and n-hexane. So that the workers can be exposed to those chemical compounds through inhalation and skin absorption. Oral intake even has also been reported in some cases.

Shoe industries use raw materials, such as toluene. This chemical material when inhaled into the body will undergo Phase I and Phase II biotransformation. Studies on human biotransformation and elimination systems have continually been developed12. Various clinical and in vivo studies have also been conducted to evaluate the effects of food and its components on detoxification, including phase I of cytochrome P450 enzyme and phase

II of conjugation enzymes. In Phase I biotransformation, toluene will perfectly generate benzoic acid, and it will react with glycine, part of the protein in Phase II biotransformation, to generate hippuric acid excreted through urine. This first phase of the biotransformation of toluene into benzoic acid is highly dependent on the role of cytochrome P450. Next, benzoic acid will react with glycine to generate hippuric acid, and in urine this can be used as an indicator of toluene detoxification.

Based on the results of a research conducted by the USDA $_{16}$ is used for data comparison and analisys.

\section{MATERIAL AND METHOD}

This research is an experimental study using certain treatments for the research subjects consisting of workers exposed to toluene at some shoe homeindustries. Before working, the workers were examined for hippuric acid level in their urine. The workers were then given food rich in glycine to eat. Food containing glycine given to the workers includes tomatoes, beans, spinach, asparagus, garlic, tuna, and milk. Those kinds 
of food in the form of vegetables, fish, and milk with the same weight were given to each worker. After three days of consuming food containing glycine, the workers were examined again for hippuric acid level in their urine. Hippuric acid level before and after the meals contained in their urine were then compared to determine the effects of food containing glycine on the level of hippuric acid excreted in their urine.

The number of the research subjects in this research was 20 workers from Tambak Oso Wilangun area. The independent variables in this research were toluene vapor exposure with a unit of $\mathrm{mg} / \mathrm{m}_{3}$, while the dependent variables were hippuric acid levels in urine with a unit of $\mathrm{mg} / \mathrm{L}$.

To examine the differences in the levels of toluene and hippuric acid between the treated group and the untreated group, unpaired $\mathrm{T}$ test was performed.

\section{FINDINGS}

a. General Description of the Research Location

Two types of glue used in the gluing process for shoe home industry: yellow glue (Super SM brand) as well as white glue and LK glue (PU-Weber, DS-Bond DNS 818). Yellow glue is used to join opening parts, and white glue is generally used to patch sole due to its stronger adhesive power. In weekdays, they can spend $30-40 \mathrm{~kg}$ of yellow glue and $30 \mathrm{~kg}$ of white glue. Glue is poured it into small containers, or by directly using the container of the glue weighed $3 \mathrm{~kg}$.

The workers usually glue using their fingers directly without gloves and masks. The air condition is very hot with terrible glue fume smell. Most workers even work shirtless, smoke, eat and also rest or sleep in the same area.

The condition of the workers is more or less the same as the other shoe craftsmen in general. The working environment is poorly ordered, all section were all located in the same room together with the storage place of other raw materials. In addition, the ventilation system is inadequate and lack of exhaust fans or even without any fans.

b. Concentrations of Toluene in the Workplaces

Table 1 shows the concentrations of toluene in the shoe home-industries. The toluene concentration measurement in a unit of ppm and in temperature of celsius degrees was performed by UPT K3 Hiperkes in East Java Province. The measurement results are shown in the table below.

Table 1. Concentrations of Toluene in the Workplaces

\begin{tabular}{|l|l|l|l|l|l|l|l|l|}
\hline Location & $\begin{array}{l}\text { Time } \\
(\text { Wib) }\end{array}$ & $\begin{array}{l}\text { Toluena } \\
\text { concentrations } \\
(\mathbf{p p m})\end{array}$ & $\begin{array}{l}\text { Dry } \\
\text { Temperature }\end{array}$ & $\begin{array}{l}\text { Temperature } \\
\text { in o Kelvin }\end{array}$ & K x R & $\begin{array}{l}\text { \#Ppm } \\
\mathbf{X M}\end{array}$ & $\begin{array}{l}\text { Toluena } \\
\text { levels } \\
\left(\mathbf{m g} / \mathbf{m}_{3}\right.\end{array}$ & Note: \\
\hline A & 12.22 & 138.882 & 31.7 & 304.7 & 24.99 & 12789.5 & 511.8 & $>$ \\
\hline B & 12.35 & 4.246 & 32.8 & 305.8 & 25.075 & 391.9 & 15.6 & $<$ \\
\hline C & 12.50 & 10.763 & 31.9 & 304.9 & 25.042 & 991.6 & 39.6 & $<$ \\
\hline D & 12.59 & 4.413 & 32.4 & 305.4 & 25.042 & 406.6 & 16.23 & $<$ \\
\hline E & 13.07 & 11.264 & 32.6 & 305.6 & 25.059 & 1037.8 & 41.41 & $<$ \\
\hline F & 13.30 & 0.968 & 30.9 & 309.9 & 25.387 & 89.2 & 3.51 & $<$ \\
\hline G & 13.33 & 0.675 & 30.9 & 303.9 & 24.920 & 62.3 & 2.50 & $<$ \\
\hline H & 13.40 & 0.212 & 31.6 & 304.6 & 24.980 & 19.5 & 0.78 & $<$ \\
\hline I & 13.50 & 0.878 & 31.7 & 304.7 & 24.990 & 80.9 & 3.23 & $<$ \\
\hline
\end{tabular}

Note: NAB toluene $168 \mathrm{mg} / \mathrm{m}_{3}$. (<: Less than NAB,>: greater than NAB) 
Based on Permenakertrans No.13 of 2011, the standard reference of the normal toluene concentration in working environment is $168 \mathrm{mg} / \mathrm{m}_{3}$. As shown in Table 1 above, the highest level of toluene in location A was 511.8 $\mathrm{mg} / \mathrm{m}_{3}$, while the smallest concentration of $0.78 \mathrm{mg} / \mathrm{m}_{3}$ in Location $\mathrm{H}$, and the average concentration

Table 2. Glycine Weights at Each Meal Time was $70.52 \mathrm{mg} / \mathrm{m}_{3}$.

\section{c. Glycine Weights in Food}

Types of food and meal time as indicated in the table below.

\begin{tabular}{|c|c|c|c|c|c|c|c|c|}
\hline No & $\begin{array}{l}\text { Days } \\
\text { (Meal Time) }\end{array}$ & Types of Fo & d (g) & & & & & $\begin{array}{l}\text { Glycine } \\
\text { Weight }(\text { o })\end{array}$ \\
\hline 1 & $\begin{array}{l}\text { Saturday } \\
\text { (Breakfast) }\end{array}$ & $\begin{array}{l}\text { Spinach } \\
80 \mathrm{gr}\end{array}$ & $\begin{array}{l}\text { Glycine } \\
\text { weight } \\
80 / 100 \times \\
0.645= \\
0.516\end{array}$ & $\begin{array}{l}\text { Pepes tuna } \\
100 \mathrm{gr}\end{array}$ & $\begin{array}{l}\text { Glycine weight } \\
1.436\end{array}$ & - & & 1.952 \\
\hline 2 & $\begin{array}{r}\text { Saturday } \\
\text { (Lunch) }\end{array}$ & $\begin{array}{l}\text { Stir-fried } \\
\text { green beans } \\
70 \mathrm{gr}\end{array}$ & $\begin{array}{l}70 / 172 \\
X 0,6 \\
0.244\end{array}$ & $\begin{array}{l}\text { Leeks } \\
33 \mathrm{gr}\end{array}$ & $\begin{array}{l}33 / 112 \\
X 3,47 \\
1.022\end{array}$ & $\begin{array}{l}\text { Fried } \\
\text { tempeh } \\
20 \mathrm{gr}\end{array}$ & $\begin{array}{l}20 / 100 \\
X 1,38 \\
0.276\end{array}$ & 2.509 \\
\hline 3 & $\begin{array}{l}\text { Saturday } \\
\text { (Dinner) }\end{array}$ & $\begin{array}{l}\text { Leeks } \\
33 \mathrm{~g}\end{array}$ & 1.022 & $\begin{array}{l}\text { Stir-fried } \\
\text { yard long } \\
\text { beans } \\
70 \mathrm{gr}\end{array}$ & $\begin{array}{l}70 / 100 \\
\mathrm{x} 1,73 \\
1.211 \\
\end{array}$ & $\begin{array}{l}\text { Fried } \\
\text { tempeh } \\
20 \mathrm{gr}\end{array}$ & 0.276 & 2.509 \\
\hline 4 & $\begin{array}{l}\text { Sunday } \\
\text { (Breakfast) }\end{array}$ & $\begin{array}{l}\text { Yard long } \\
\text { beans } \\
70 \mathrm{gr}\end{array}$ & 1.211 & $\begin{array}{l}\text { Leeks } \\
25 \mathrm{gr}\end{array}$ & 1.022 & \begin{tabular}{|l|} 
Fried \\
tempeh \\
$20 \mathrm{gr}$ \\
\end{tabular} & 0.276 & 2.509 \\
\hline 5 & $\begin{array}{l}\text { Sunday } \\
\text { (Lunch) }\end{array}$ & $\begin{array}{l}\text { Tuna } \\
100 \mathrm{gr} \\
\end{array}$ & 1.436 & $\begin{array}{l}\text { Stir-fried } \\
\text { yard long } \\
\text { beans } \\
70 \mathrm{gr}\end{array}$ & 1.211 & $\begin{array}{l}\text { Fried } \\
\text { tempeh } \\
20 \mathrm{gr} \\
\end{array}$ & 0.276 & 2.923 \\
\hline 6 & $\begin{array}{l}\text { Sunday } \\
\text { (Dinner) }\end{array}$ & $\begin{array}{l}\text { Seaweed } \\
70 \mathrm{gr}\end{array}$ & $\begin{array}{l}70 / 100 \\
X 3.009= \\
2.11\end{array}$ & $\begin{array}{l}\text { Paprika } \\
(33 \mathrm{~g})+ \\
\text { tempeh } \\
(20 \mathrm{~g})\end{array}$ & $\begin{array}{l}33 / 100 \\
X 0,66=0.22 \\
+0.276= \\
\\
0.496\end{array}$ & $\begin{array}{l}\text { Tuna } \\
100 \mathrm{gr}\end{array}$ & 1.436 & 4.43 \\
\hline 7 & $\begin{array}{l}\text { Monday } \\
\text { (Breakfast) }\end{array}$ & $\begin{array}{l}\text { Yard long } \\
\text { beans with } \\
\text { peanut } \\
\text { sauce } \\
70 \mathrm{gr}\end{array}$ & 1.211 & $\begin{array}{l}\text { Fried } \\
\text { tempeh } \\
20 \mathrm{gr}\end{array}$ & 0.276 & - & & 1.487 \\
\hline 8 & $\begin{array}{l}\text { Monday } \\
\text { (Lunch) }\end{array}$ & $\begin{array}{l}\text { Tuna } \\
100 \mathrm{gr} \\
1.436\end{array}$ & & $\begin{array}{l}\text { Green } \\
\text { Beans } \\
70 \mathrm{gr}\end{array}$ & 0.244 & \begin{tabular}{|l|} 
Fried \\
tempeh \\
$20 \mathrm{gr}$ \\
\end{tabular} & 0.276 & 1.956 \\
\hline
\end{tabular}

Based on the table above, the greatest weight of glycine consumed by the workers was on day six which was 4.43 grams. Meanwhile, the smallest was on day 7 which was $1.487 \mathrm{~g}$, and the mean weight of glycine per one meal was $2,534 \mathrm{~g}$.

d. The Measurement Results of Hippuric Acid Levels

The results of the measurement of hippuric acid levels before and after the administration of food containing glycine were as follow: 
Table 3. Hippuric Acid Levels before and after the Administration of Food Containing Glycine

\begin{tabular}{|c|c|c|}
\hline No. Sample & $\begin{array}{l}\text { Hippuric Acid Levels } \\
\text { in the urine }(\mathrm{g} / \mathrm{L}) \text { on } \\
\text { June } 12,2015\end{array}$ & $\begin{array}{l}\text { Hippuric Acid } \\
\text { Levels in the } \\
\text { urine }(\mathrm{g} / \mathrm{L}) \text { on } \\
\text { June } 15,2015\end{array}$ \\
\hline 1 & 0.56 & 1.12 \\
\hline 2 & 0.51 & - \\
\hline 3 & 0.58 & 0.35 \\
\hline 4 & 0.79 & 0.35 \\
\hline 5 & 0.35 & 0.19 \\
\hline 6 & 0.61 & 0.59 \\
\hline 7 & 0.53 & 1.14 \\
\hline 8 & 0.41 & 0.98 \\
\hline 9 & 0.48 & 0.52 \\
\hline 10 & 0.40 & 0.98 \\
\hline 11 & 0.68 & 0.31 \\
\hline 12 & 0.19 & 0.70 \\
\hline 13 & 0.49 & - \\
\hline 14 & 0.08 & 0.65 \\
\hline 15 & 0.27 & 0.44 \\
\hline 16 & 0.05 & 1.63 \\
\hline 17 & 0.78 & 1.06 \\
\hline 18 & 0.11 & 0.75 \\
\hline 19 & 0.37 & 0.75 \\
\hline 20 & 1.47 & 0.68 \\
\hline Total & 9.71 & 11.69 \\
\hline Mean & 0.4855 & 0.649 \\
\hline
\end{tabular}

Table 3 above shows that the mean level of hippuric acid prior to the administration of food rich in glycine was $0.4855 \mathrm{mh} / \mathrm{L}$, while the mean level of hippuric acid after the administration was $0.649 \mathrm{mg} / \mathrm{L}$. It indicates that there was an increase in the excretion of hippuric acid after the administration of food rich in glycine. This means, it can accelerate the increase in the excretion of hippuric acid, about $(0.164 \mathrm{~g} / \mathrm{l} / 0.4855)$ $\mathrm{x} 100 \%=33.8 \%$.

e. The Correlation between Toluene Concentrations in the Air and Benzoic Acid Concentrations in the Blood

To decrease the concentrations of toluene in homeindustries, it is necessary to repair the ventilation by using natural ventilation or artificial ventilation. Natural ventilation is made by using a window with an area of at least 1/5 - 1/6 of floor space. Artificial ventilation is made by using a scrubber designed specifically for toluene vapor.

The regression equation used for the correlation between the concentrations of toluene in the air and the concentrations of benzoic acid in the blood is as follows:

$$
\mathrm{Y}=0.599 \mathrm{x} \mathrm{mg} / \mathrm{L} / \mathrm{h}+15.23 \text {, with } \mathrm{r}=0.123
$$

By using the regression equation above, it can be estimated the concentration of benzoic acid in the blood of the workers at the toluene concentration of 511.8 $\mathrm{mg} / \mathrm{m}_{3}$ was as follows:

$$
\mathrm{Y}=0.599(511.8)+15.23=321.8 \mathrm{mg} / \mathrm{L} / \mathrm{h}=
$$
$2574.4 \mathrm{mg} / \mathrm{L}$ (for 8 hours)

With the same equation for toluene concentration $0.78 \mathrm{mg} / \mathrm{m}_{3}, \mathrm{Y}=15.697 \mathrm{mg} / \mathrm{L}=376.728 \mathrm{mg} / \mathrm{L}$ (for 8 hours), and for concentration $70.52 \mathrm{mg} / \mathrm{m}_{3}, \mathrm{Y}=57.47$ $\mathrm{mg} / \mathrm{L}=459.76 \mathrm{mg} / \mathrm{L}$ (for 8 hours)

\section{f. Concentrations of Hippuric Acid in the Urine}

As shown on Table 2 above, the largest consumed glycine was 4.43 grams on day 6 while the smallest one was $1.487 \mathrm{~g}$ on day 7 . The mean weight of glycine per one meal was $2.534 \mathrm{~g}$.

The mean blood volume in a person weighed $70 \mathrm{~kg}$ is 5 liters. If all glycine was absorbed with an average of 2.534 grams per one meal or 7.602 grams/day, the mean level of glycine in the blood would be $7.602 \mathrm{~g} / 5$ liters of blood or $1.5204 \mathrm{~g} / \mathrm{L}$.

The concentration of hippuric acid in the urine before intaking was $0.4855 \mathrm{~g} / \mathrm{L}$ and it became 0.649 $\mathrm{g} / \mathrm{L}$ after intaking. Therefore, there was an increase in the urinary excretion of $33.8 \%$.

Based on the guidelines, biological exposure index of hippuric acid in urine is $2.5 \mathrm{~g} / \mathrm{g}$ creatinine; whereas, toluene level in blood is $1.0 \mathrm{mg} / \mathrm{L}$. Meanwhile, the concentration of hippuric acid in adults is $0.44 \pm 0.20$ $\mathrm{g} / \mathrm{L}$ which is equivalent to $0.7 \mathrm{~g} / \mathrm{g}$ creatinine 14 . Unlike the previous researcher, that the exposure to $100 \mathrm{ppm}$ of toluene at the end of the work shift can trigger the concentration of hippuric acid into $0.4 \mathrm{~g} / \mathrm{L}$ which is equivalent to $5 \mathrm{~g} / \mathrm{g}$ creatinine ${ }_{11}$. On the other hand, the maximal concentration of hippuric acid is $2.5 \mathrm{~g} / \mathrm{g}$ creatinine with a normal range of $1.5 \mathrm{~g} / \mathrm{g}$ creatinine 10 .

Based on those references, the concentration of hippuric acid in urine is $0.649 \mathrm{~g} / \mathrm{L}$ which is equivalent to $8.1125 \mathrm{~g} / \mathrm{g}$ creatinine obtained from $(0.649 \mathrm{~g} / \mathrm{L}: 0.4$ $\mathrm{g} / \mathrm{L}) \times 5 \mathrm{~g} / \mathrm{g}$. The normal concentration of hippuric acid is $2.5 \mathrm{~g} / \mathrm{g}$ creatinine ${ }_{1}$; whereas, it is $1.5 \mathrm{~g} / \mathrm{g}$ creatinine ${ }_{10}$. The concentration of hippuric acid in the urine of the workers in this research is considered to be abnormal. 
If the standard reference by ACGIH is used, it should be lowered again to $2.5 \mathrm{~g} / \mathrm{g}$ creatinine or (8.1125 to 2.5 ) or $5.6125 \mathrm{~g} / \mathrm{g}$ creatinine or $69.1 \%$.

The molecular weight of hippuric acid is 179.17 $\mathrm{g} / \mathrm{mol}$ while the molecular weight of glycine is 75.0699 $\mathrm{g} / \mathrm{mol}$. In addition, the molecular weight of benzoic acid is $122 \mathrm{~g} / \mathrm{mol}$. The mean molecular weight of hippuric acid excreted is $0.0036 \mathrm{~mol} / \mathrm{L}$ derived from $0.649 \mathrm{~g} / \mathrm{L}$

: $179.17 \mathrm{~g} / \mathrm{mol}$. The mean molecular weight of benzoic acid is $459.76 \mathrm{mg} / \mathrm{L}$ or $0.45976 \mathrm{~g} / \mathrm{L}$ which is equal to $0.0038 \mathrm{~mol}$ derived from $0.45976 \mathrm{~g} / \mathrm{L}: 122 \mathrm{~g} / \mathrm{mol}$.

It can be said that for benzoic acid at a mean concentration of $0.0038 \mathrm{~mol} / \mathrm{L}$, the concentration of glycine that must be taken is $0.0038 \mathrm{~mol} / \mathrm{L}$ in 8 hours in order to excrete entire benzoic acid into hippuric acid. As a result, for glycine with a molecular weight of $75.0699 \mathrm{~g} / \mathrm{mol}$, the weight of glycine needed is $0.285 \mathrm{~g}$ within 8 working hours, obtained from $0.0038 \mathrm{~mol} / \mathrm{L} \mathrm{x}$ $75.0699 \mathrm{~g} / \mathrm{mol}$. Meanwhile, the mean weight of glycine given to the research subjects in each meal was $2,534 \mathrm{~g}$ at breakfast, lunch, and dinner. If the normal weight of glycine in one meal is 2.534 grams within 8 working hours, that there is an excess of about 2.249, obtained from $2.534 \mathrm{~g}-0.285$ grams, in the food given to the research subjects to lower the levels of toluene and benzoic acid from their body.

For those reasons, for those workers in the work environment containing the highest toluene concentration of $511.8 \mathrm{mg} / \mathrm{m}_{3}$ with the benzoic acid concentration of $2574.4 \mathrm{mg} / \mathrm{L}$ or $2.5744 \mathrm{~g} / \mathrm{L}$, equivalent to $0.021 \mathrm{~mol} / \mathrm{L}$, as much as $0.021 \mathrm{~mol} / \mathrm{L}$ glycine which is equal to 15.765 gram glycine derived from $0.21 \mathrm{~mol} / \mathrm{L} \times 75.0699 \mathrm{~g} / \mathrm{mol}$ is required to lower the benzoic acid concentration. The portion of food containing glycine needs to be increased to $15.765 \mathrm{~g} / 2.534 \mathrm{~g}$ or 6.22 times greater than the mean portion of glycine given during the research.

\section{CONCLUSION}

Based on the results of this research, it can be concluded that:

a. The mean concentration of toluene in this research was $70.52 \mathrm{mg} / \mathrm{m}_{3}$ which was still below the standard reference of the normal toluene concentration recommended by Permenakertrans No.13 of 2011 (168 $\mathrm{mg} / \mathrm{m}_{3}$ ). The level of toluene in the shoe home-industry A was $511.8 \mathrm{mg} / \mathrm{m}_{3}$. This high concentration of toluene in the shoe home-industries was due to poor ventilation.

b. The mean concentration of hippuric acid in the urine before intaking food rich in glycine was 0.4855 $\mathrm{g} / \mathrm{L}$ while the mean concentration of hippuric acid in the urine after intaking food containing glycine was $0.649 \mathrm{~g} / \mathrm{L}$. It means that there was an increase in the urinary excretion of about $33.8 \%$.

Conflicts of Interest: All authors have no conflicts of interest to declare.

Source of Funding: This is an article "Detoxification of Benzoid Acid in Workers Exposed to Toluene Using Food Rich in Glycine" was supported by Activity Budget Plans 2017, Faculty of Public Health, Airlangga University.

Ethical Clearance: The study was approved by the institutional Ethical Board of the Public Health, Airlangga University.

All subjects were fully informed about the procedures and objectives of this study and each subject prior to the study signed an informed consent form.

\section{REFERENCES}

1. ACGIH. (2005). TLVs and BEIS. Worldwide, Cincinnati.

2. Amin, M. (1996). Penyakit Paru Obstruktif Menahun : Polusi Udara, Rokok dan Alfa-1Antitripsin, Airlangga University Press, Surabaya.

3. Beata Janasik, et.al. (2010). Unmetabolized VOCs in Urine as Biomarkers of Low Level Occupational Exposure. International Journal of Occupational Medicine and Environmental Health 2010;23(1): DOI 10.2478/v10001-010-0003-x (p.21-26)

4. Clayton,et.al. (1993). Pattys Industrial Hygiene and Toxicology, Jihniley and Sons,inc. Singapore.

5. Hodgson, E.,Patricia L. (2000). Modern Toxicology - Second Edition, Mc.Graw Hill, Boston

6. Jeremy,P.,T. (2007). At a Glance : Sistem Respirasi, Edisi kedua, Erlangga, Jakarta.

7. Klaassen,Watkins J. Casarett and Doul's (2003). Essential of Toxicology,McGraw-Hill, Toronta, Canada.

8. Kuntoro. (2010). Metode Sampling dan Penentuan Besar sampel, Pustaka Melati, Surabaya. 
9. NIOSH. (1980) Manual of Analytical Methods, 2nd Ed., Vol. 6, Method P\&CAM 327, U.S. Department of, Health and Human Services, Publ. (NIOSH) (p. 80-125).

10. Lauwerys, R.R. (1983). Industrial Chemical Exposure: Guidelines for Biological Monitoring, Biomedical, Publications, Davis, California, (p.57-65)

11. Pagnotto, LD. \& Ueberman, LM. (1967) Urinar hippuric acid excretion as an index of toluene ex sure. Am ind. Hyg. As. 1.,28, (p. 12-13)

12. Romilly E. Hodges and Deanna M.Minich. (2015). Modulation of Metabolic Detoxification Pathways Using Foods and Food-Derived Components: A Scientific Review with Clinical Application. 